\title{
Obituaries
}

Obituaries should be submitted by email to Jadene Doak at jadene.doak@springernature.com

All submitted obituaries should be 400 words maximum in length (apart from obituaries for past presidents of the BDA where the length should be 800 words).

Content of the obituary is down to the individual author, and the approval of the family should be given for the obituary prior to submission to the BDJ.

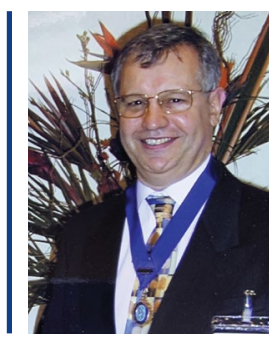

\section{Andrew Hyatt}

1948-2021

It is with great sadness that the death of Dr Andrew Hyatt was announced on 15 June. Andrew was born in Bristol in 1948 and educated at King Edward VI School, Bath. He began studying for a degree in Dental Surgery at the University of Bristol. Whilst at Bristol, he took a hiatus from dentistry and embarked upon a BSc in biochemistry, gaining a $\mathrm{PhD}$ in the subject in 1976. Andrew then qualified as a dental surgeon and became both a lecturer in biochemistry and an undergraduate teacher in restorative dentistry, specialising in endodontics at University College Hospital (UCH), London. He eventually became senior lecturer and honorary consultant there.

Andrew was a past President of the British Endodontic Society, lecturing widely on the subject, and was a former partner at Lister House Endodontic Practice in Wimpole Street. Andrew spawned a generation of UCH students who admired him greatly and always viewed him with huge affection.

To call Andrew a Renaissance man would be an oversimplification of his many talents and interests. Apart from his brilliant and analytical scientific mind and unquestionable clinical skills, which made him a sought-after and highly respected London specialist, he had a deep love and understanding of philosophy, history, poetry and literature. He wrote beautifully, modestly describing his penmanship as 'scribbles'

Along with music, especially the guitar blues of the Mississippi Delta, his other great love was wine. His knowledge, rigour and forensic ability to understand and interpret a 'beaker full of the warm south' was impressive, to say the least. He spoke entertainingly on the subject to many wine societies and at formal tastings. However, his love of wine was not just a sign of his enviable intellect and taste; his enjoyment in sharing his finest bottles and the conviviality and joy it brought others were a sign of his warmth and generosity.

Andrew was diagnosed with a terminal illness in 2019 and had been parrying this unwelcome intruder with stoicism and strength until he lost his fight at his home in Cromer last month. He leaves behind his devoted wife, Zoe, and his daughter Isabelle. Mubariz Hussain

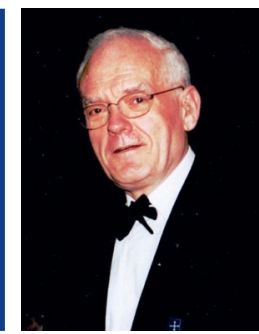

Malcolm Simpson

1936-2021

Malcolm was born in South Shields, where he attended secondary school. He began his university life at Newcastle in 1954 and qualified BDS Dunelm in 1959. He then embarked on two years of National Service, mostly spent in Kenya. On his return to England in 1961, he worked for a few years in general practice in Newcastle upon Tyne. In 1965, he bought a practice in Stockton-on-Tees at which he worked successfully until he retired in 1996.

Malcolm was a highly respected member of the dental profession. He was a longstanding member of Cleveland LDC and an active member of the North of England Odontological Society and Newcastle Dental Graduates Association. He was also a regional referee for the Sick Dentist Scheme.

Malcolm was a long-standing member of the BDA. He was a past President of the North Yorkshire, South Durham and Cleveland BDA section and also a past President of the Northern Counties Branch. He was delighted to be awarded Honorary Life membership of the BDA in 1999.

Malcolm led a very active life, being involved in many organisations where he was renowned for his legendary quick wit and wisdom, and was held in high esteem. He was awarded the Paul Harris Fellow of Rotary Club recognition, having served as Secretary, President and active fundraiser over many years.

Malcolm was married to Meg for 57 years. They have two daughters, Karen (BDS Newcastle, 1987) and Jane (BDS Newcastle, 1991), both of whom worked alongside him in Stockton. He had four grandchildren that he absolutely adored; he was never happier than when he spent time with them all.

He suffered a major stroke in 2018, and after some months in hospital and a nursing home, he was able to be nursed at home and enjoy the garden he loved. He died peacefully in his sleep on 20 February 2021.

He will be long remembered for his wit and totally endearing personality. He will be greatly missed by all who knew him.

Meg Simpson 